\title{
Placental Villous Stromal-Vascular Karyorrhexis
}

National Cancer Institute

\section{Source}

National Cancer Institute. Placental Villous Stromal-Vascular Karyorrhexis. NCI

Thesaurus. Code C118154.

Three or more foci of two or more placental terminal villi showing karyorrhexis of fetal cells with preservation of the surrounding trophoblast. The villi may also show stromal hypercellularity and mineralization, and can either be hypovascular or only exhibit capillary degenerative changes. Entrapped red blood cells and red blood cell fragments are often seen. 